\title{
Universiteit
}

Leiden

The Netherlands

\section{Opportunistic accountability: state-society bargaining over shared interests}

Grossman, S.; Phillips, J.P.; Rosenzweig, L.R.

\section{Citation}

Grossman, S., Phillips, J. P., \& Rosenzweig, L. R. (2017).

Opportunistic accountability: state-society bargaining over shared interests. Comparative Political Studies, 51(8), 979-1011. doi:10.1177/0010414017720706

Version:

Publisher's Version

License:

Licensed under Article 25fa

Copyright Act/Law (Amendment

Taverne)

Downloaded from: $\quad$ https://hdl.handle.net/1887/3263716 


\title{
Opportunistic Accountability: State-Society Bargaining Over Shared Interests
}

Comparative Political Studies 2018, Vol. 5I(8) 979-10II

(C) The Author(s) 2017

Reprints and permissions: sagepub.com/journalsPermissions.nav DOI: $10.1177 / 0010414017720706$ journals.sagepub.com/home/cps

@SAGE

\section{Shelby Grossman', Jonathan Phillips², and Leah R. Rosenzweig ${ }^{3}$}

\begin{abstract}
Conflicting preferences between the state and society underpin most accountability mechanisms by providing a credible way for society to impose costs on the state. Adapting a classic bargaining framework, we argue that broader conditions can support state-society bargaining. Policies that both the state and society value can also enhance society's negotiating power, provided society has a relatively lower valuation and is more patient than the state. By threatening to sabotage their own interests but hurt the impatient state even more, citizens can compel the state to deliver broader policy benefits. We illustrate this logic with the case of polio vaccination in northern Nigeria, where entire communities have resisted the vaccine as a strategy to bargain for more desired services. To resolve and preempt noncompliance, the Nigerian government has enhanced service delivery in other areas, demonstrating the opportunity for improved accountability in the presence of shared-interest policies.
\end{abstract}

\section{Keywords}

African politics, health politics and policy, quality of democracy, state building

\footnotetext{
'University of Memphis, TN, USA

${ }^{2}$ Harvard University, Cambridge, MA, USA

3Massachusetts Institute of Technology, Cambridge, USA
}

\section{Corresponding Author:}

Shelby Grossman, Department of Political Science, University of Memphis, Clement Hall, Walker Avenue, Memphis, TN 38I II, USA.

Email: sgrssman@memphis.edu 


\section{Introduction}

At the root of society's ability to extract accountability from the state is its ability to impose costs on the government. In the toolbox of accountability mechanisms that scholars have documented, this means that society must possess both the capacity to block a government policy and the desire to avoid that policy if it is to credibly threaten noncompliance and extract concessions on other policy dimensions. It is citizens' inherent reluctance to pay taxes that may induce better public service provision, forming the fiscal contract (Timmons, 2005). It is the passionate beliefs of protesters opposed to construction that damages the environment that forces mitigation efforts. And it is political competition for voter support that catalyzes greater efforts to fix potholes and keep lights on. In many contemporary developing countries, however, governments need not extract resources from citizens, protest is dangerous, and elections are ineffective as a channel of accountability. In these places, the prospect for accountable government and a strong social contract appears dim.

In this article, however, we argue that it is not strictly necessary that citizens desire to avoid a policy to use noncompliance as a bargaining strategy. Under certain conditions, society and the government's shared preference for a policy is capable of increasing government accountability. In a single iteration bargaining game between the state and society - the framework of existing theoretical models - society's threats to work against its own preferences are simply not credible. By introducing a repeated framework that evolves over time with discounting of the future, in line with the classic Rubinstein (1982) bargaining model and real-world interactions, we show how these threats of noncompliance can become credible. Specifically, where the state values the policy more than society and is less patient, the costs of delay that society can impose on the state through noncompliance are substantial. This creates an incentive for the state to offer earlier concessions, and those concessions create the expected bargaining gains for society that can outweigh the short-term loss to society of noncompliance. This makes the threat of noncompliance with a desired policy ex ante credible.

We illustrate how these conditions can enable accountability by examining the case of polio vaccination in northern Nigeria. This geographic focus is valuable because communities in northern Nigeria lack many tools to impose costs on the state. The rentier state has avoided taxation, a centralized media makes protesting ineffective and clientelism undermines electoral institutions. Yet, there is a highly salient policy that citizens have the capacity to resist: polio vaccination. Multiple times per year, immunization teams visit every family's house to deliver the vaccine to children under the age of 5 . 
Crucially, citizens value this vaccine. We demonstrate that the presence of a vaccination worker at their door can be just as politically empowering as receiving a visit from the tax collector.

As we document through observational data and interviews, whole communities frequently resist polio vaccination even though they want their children to be vaccinated. We document how these "block rejection" tactics have been explicitly used by communities as a bargaining tool to demand other benefits such as electricity and clean water from the state. Perceiving these strategies as credible threats, the state has often responded positively, producing increased accountability. The Nigerian government now preemptively tries to meet community demands through the implementation of health camps, which provide a wide range of basic health services more desired than polio vaccination.

Our contribution is therefore to show how social contract dynamics can result from not just "sacrificial" policies but also "disbursement" policies where it is costless for citizens to comply (Lieberman, 2009). Refining the theoretical framework for accountability broadens the scope conditions under which society can extract benefits. The empirical evidence from Nigeria provides a confirmatory test that shared-interest policies can indeed materially boost accountability. Notably, our theory does not rely on communities possessing prior political resources before they can initiate bargaining with the state. For this reason, it is a potentially powerful "weapon of the weak" (Scott, 1985) that may serve as an alternative pathway to citizen-state bargaining. We label such a process "opportunistic accountability" because (a) citizens' threats of noncompliance are not principled rejections of the policy but a strategic exploitation of the circumstances to secure their own goals, (b) the roots of the new bargaining power depend on shared preferences rather than solely on the agency of citizens, and (c) the tactic is widely available to any group of citizens who recognizes the opportunity, regardless of their preexisting socioeconomic or political resources.

Polio vaccination is one example of a class of increasingly salient governance issues, which require broad, decentralized compliance and where both society and the state value effective implementation. As a result, similar bargaining processes to those in northern Nigeria have been documented across the developing world. In India, parents have resisted polio vaccination to bargain with the state for electricity, ${ }^{1}$ access to preschool for their children, ${ }^{2}$ and improved safety around a railroad crossing point. ${ }^{3}$ In Pakistan, community leaders have boycotted the polio vaccine to bargain for local electrification. ${ }^{4}$ In Jordan, Syrian refugees temporarily refused water to compel the delivery of food aid as well. ${ }^{5}$ In short, society's bargaining power need not rely on intrinsic disagreement with the state. 
In the remainder of this article, we first summarize the accountability literature and outline a bargaining framework where common interests are consequential. The section "Establishing the Conditions for Bargaining in Nigeria's Polio Eradication Campaign" justifies our empirical focus on the Nigerian polio campaign by using monitoring and survey data to demonstrate that polio vaccination is indeed a shared interest and that the assumptions of the theory of opportunistic accountability are met. In the section "Evidence of Opportunistic Accountability," we use observational data and case studies to describe how state-society bargaining has occurred and the social contract strengthened.

\section{Accountability and Shared-Interest Policies}

Research frequently attributes accountable government to the existence of a social contract - a mutual exchange — between the state and citizens. In the paradigmatic case, the social contract is a fiscal contract; the pressures of external conflict compel elites to extract taxes from citizens (Levi, 1989; Tilly, 1992). Yet, eager to retain their own income and free ride on the contributions of others, citizens are reluctant to pay taxes. Two necessary characteristics of taxation are argued to enable the redistribution of political bargaining power toward society. The first is that citizens are capable of evading taxation and denying revenue to the state, providing a mechanism for imposing costs on the state. The second characteristic is that citizens dislike paying taxes, all else equal. Where the government falls short on its obligations, it knows that citizens will be eager to withhold taxation. The combination of the ability and preference for policy noncompliance underpin the equilibrium of "quasi-voluntary" compliance and governmental accountability, with citizens and the state engaging in a quid pro quo, exchanging tax payments for public goods (Levi, 1989).

How essential is it that society is hostile toward a policy for that policy to boost accountability? Existing accounts suggest a crucial reason why a conflict of interest between state and society may be necessary: the credibility of societal resistance. When negotiating with the state, society's threat to block or sabotage a policy from which it stands to benefit appears irrational; if society is only hurting itself, this will do nothing to improve its bargaining position. Knowing this, there is no reason for the state to make concessions in any other policy area. This logic has been directly incorporated into formal models of accountability. Consider, for example, the formalizations of Hirschman's voice and exit argument in Clark, Golder, and Golder (2017) and Gehlbach (2006). In both cases, voice - getting government to listen and increase public benefits - is only effective to the extent that threats of exit - in this case, 
rejecting a policy - are credible. In the single-round setup of these models, that credibility hinges on whether society would rationally resist a policy at the "end" of the game. ${ }^{6}$ Clearly, if that policy is valued, it will not be resisted, because there are no possible future gains to be achieved. For policies that citizens value (e.g., health care or better roads), the value of exit is negative, preventing accountability gains.

Other accountability mechanisms also rely on the twin pillars of the capacity and desire to block a policy. Protests seeking to block policy depend not only on the logistical means and media coverage to delay implementation or impose publicity costs but also on the intrinsic motivation of protesters to incur the opportunity costs and physical risks of participation. Electoral accountability depends on citizens having both the right to a meaningful vote and their willingness to switch to competing candidates (or opt out completely) if incumbents do not deliver. The idea that citizen sacrifice is critical for accountability gains is frequently expressed (e.g., Paler, 2013; Prichard, 2015). Hirschman's (1970) model of exit, voice, and loyalty was designed explicitly to understand how a "deleterious" change in society's environment (e.g., a new cost imposed on society) would affect bargaining outcomes.

\section{What Makes Noncompliance With Shared-Interest Policies Credible?}

The emphasis on sacrifice, we argue, is largely an artifact of a literature focused overwhelmingly on conflict-of-interest policies and of the simplified modeling framework in which accountability is often studied. In particular, the failure to incorporate the repeated and indefinite duration of state-society bargaining interactions limits the range of outcomes. To make resistance credible, society needs to be able to impose costs on the state in the future that induce the state to make bargaining concessions today, providing the positive incentive for resistance. In one-round models of accountability, it is impossible for society to impose any costs on the state because at the end of the game, there is nothing left to influence. Yet, in an indefinitely repeated game, we argue that the state is vulnerable to society in a wide range of circumstances. Its vulnerability stems directly from the fact that it also values the implementation of the policy and will face an opportunity cost if society resists. ${ }^{7}$ It is the cost of delay to the state that gives society the power to improve its bargaining position, but that power is only visible when theoretical models accommodate a realistic timeline.

To illustrate how rejecting a valued policy can be credible and boost accountability, we draw on the Rubinstein bargaining framework that fully 
models the passage of time while bargaining takes place. Rejecting a jointly valued policy is equivalent to destroying the bargaining surplus: "money burning." As Avery and Zemsky (1994) argue, the credibility of money burning depends not on whether each side values money - clearly they do-but on comparing "weighted losses from money burning to the individual players" (p. 6). Where the weighted loss falls mostly on the state, society's resistance becomes credible despite the harm it inflicts on itself. By threatening to "hurt them more than they hurt me," society can enhance its bargaining power and extract concessions from the state.

To formalize this logic, the online appendix describes an adapted bargaining model and the conditions under which these predictions hold. The comparative statics of the model demonstrate that society is better able to exert accountability where (a) the government values the shared-interest policy relatively more than society, (b) the government values the shared-interest policy highly compared with other policy dimensions, and (c) the government is more impatient than society. These predictions are consistent with the intuition that society has more bargaining power where it has a relatively weaker preference for the shared-interest policy. Under these conditions, the costs of delay accumulate asymmetrically on the state.

The government's impatience and relatively higher valuation of the shared-interest policy has multiple effects: First, it prevents the government from walking away from negotiations and unilaterally deciding on policy. Second, this in turn gives society the chance to impose asymmetric costsforegone benefits from the policy-on the government. The state seeks to avoid these costs through bargaining concessions, which in turn provide the endogenous gains that make society's threat of noncompliance credible. Third, the relative bargaining power continues to tilt further in society's favor, the greater the disparity in the sides' relative valuations. ${ }^{8}$ As the state becomes more eager and impatient to implement the shared-interest policy, it preemptively offers large concessions on other policy dimensions to secure a rapid agreement.

Although the model explains how shared-interest policies can generate accountability, it is not designed to predict individual acts of noncompliance. In the Rubinstein model, there are no bargaining imperfections, so the state makes preemptive concessions of greater public benefits and society never needs to follow through with its threat to resist. In practice, of course, imperfections in information are likely to lead to iterative posturing and bargaining as each side seeks to explore and learn about its opponent's intensity of preferences. In such a state of affairs, we would expect to sometimes see society not comply with a policy it values. ${ }^{9}$ 


\section{State Preferences Over Policy Implementation}

The frequency with which state and society preferences coincide is not obvious. The state's preferences are often induced by other forms of accountability that lead the state, for example, to improve the education system for electoral rewards. What matters for the shift in bargaining power are the intrinsic preferences of society and elite actors within the state. Although state elites are never perfect agents of society, there are likely to be some policy dimensions that embody no intrinsic conflict of interest. Depending on the political and socioeconomic circumstances, citizens and elites may both wish to enact policy to enforce the rule of law, clean public parks, or reduce diseases (Dionne, 2012; Lizzeri \& Persico, 2001). ${ }^{10}$

The incidence of preference coincidence may be of increasing significance in recent years because the objectives and preferences of ruling elites are increasingly diverse. It can no longer be assumed that elites are pure rent seekers who extract as much personal material benefit from the state as possible. The intangible reputational consequences of how elites govern also influence their policy choices. As many authors have emphasized, the political impetus for policy is often elite led and top-down rather than simply responsive to bottom-up or electoral demands (Evans, 1995; McLoughlin \& Batley, 2012). As global networks set increasingly differentiated rewards based on performance in office, shared interests between elites and society may become common even where institutional mechanisms of accountability remain weak. For example, the international community has established reputational and financial rewards for leaders who succeed in delivering public services to citizens, complete with benchmarks such as the Sustainable Development Goals, conditional funding through aid agencies, and highprofile awards such as the Millennium Development Goals Awards and the Mo Ibrahim Governance Prize. Promisingly, even where international or social pressures shift state preferences only on a single narrow issue, this may create broader openings as society exploits the preference overlap through opportunistic accountability. The more that environmental policy becomes a reputational issue for elites, for example, the more likely it is that social groups may turn from being environmental advocates to environmental saboteurs as they seek to rebalance the state's attention to other pressing matters.

Even broad elite preferences can create the conditions for local bargaining. Elite motivations are strongly amplified by the scale and bluntness of the state organization. Broad international targets may become rigid local policy imperatives as public employees are compelled or incentivized to take local action. For each employee, inducing compliance with a policy may then 
became crucial to their career. They may, then, be willing to make concessions on other, less supervised and less career-critical, policy dimensions to respond to blunt top-down priorities. ${ }^{11}$

\section{The Conditions Supporting Opportunistic Accountability}

Shared-interest policies do not provide the same, almost automatic, boost to accountability that conflict-of-interest policies, such as taxation, do. Their impact depends on the structure of preferences. In this section, we delineate the conditions and assumptions required for opportunistic accountability.

1. High costs to coercion, low costs to bargaining: With extreme sanctions, inducing compliance and avoiding accountability is a trivial task. We should not expect regimes that operate beyond the rule of law to be conducive sites for citizen-state bargaining to emerge. Whether the state can accommodate bilateral bargains with specific social groups may also depend on the political regime. In the strictest democracies, procedural constraints on the selective distribution of resources, autonomous bureaucracies and media coverage make isolated quid pro quos very difficult to execute. In regimes where existing patterns of public decision making are already marked by discretion and patronage, segmented bilateral bargaining may be much more feasible. Overall, this suggests that opportunistic accountability is unlikely in places where rulers are unwilling or unable to coerce compliance and most likely to be successful in patronage democracies or competitive authoritarian regimes.

2. Citizens can withhold compliance: The ability to impose costs on the state depends on society being able to frustrate the state's objectives by withholding consent. Scott (1985) outlines the range of these "foot-dragging" methods of resistance. Depending on the scale at which noncompliance imposes substantial costs on the state, citizens are likely to need to collaborate if they are to exert enough pressure to extract concessions. Any collective action problem, therefore, needs to be overcome.

3. The state values immediate policy implementation more than society: Whereas opportunistic accountability documents how citizen-state bargaining can occur in the presence of policies that both society and the state value, the credibility of society's threat depends on being able to hurt the state more than itself. That requires that the state value immediate policy implementation more than society. This can arise in two ways: a stronger intrinsic valuation of the policy or greater 
impatience (a lower discount factor in the model). If the policy being implemented is extremely valuable to citizens, for example, an urgent cure for a disease or famine relief, citizens will be unwilling to risk bargaining for additional concessions. Similarly, if the state gives the policy very low priority, it may be willing to ignore any threat of noncompliance. ${ }^{12}$

4. Citizens know state priorities: Although the opportunity to bargain may be widely available, taking advantage of this requires citizens to recognize the relatively higher value the state places on policy implementation. In some cases, this may arise through the media, through learning from other communities, or, as we argue below, directly from the incongruous intensity of the policy implementation itself. In its efforts to implement a policy priority, the state may reveal where it is vulnerable to social resistance. What may be more challenging is gaining knowledge of the specific details of the state's valuation curve for compliance. For example, if the state has set a policy goal of $90 \%$ coverage, it is futile to try and bargain once this threshold has been reached. Relatedly, the scale at which noncompliance is most effective is also crucial and may only be discovered through trial and error. The better citizens know the structure of state preferences, the more effectively they can bargain.

\section{Establishing the Conditions for Bargaining in Nigeria's Polio Eradication Campaign}

To illustrate the theory of opportunistic accountability, we use the case of northern Nigeria's polio vaccination campaign to demonstrate two otherwise puzzling outcomes: first, that communities resist a vaccine that they value, and second, that these communities compelled the state to invest considerable sums in boreholes, health care, and electricity as a result of their resistance. Verifying these processes in real-world conditions is important because there is no guarantee that the abstract logic of opportunistic accountability will be borne out in practice. The northern Nigerian polio campaign provides a valuable confirmatory test case because it meets the conditions of the theory outlined in the previous section.

\section{High Costs to Coercive Vaccination, Low Costs to Bargaining}

Although in some Nigerian states, failure to permit vaccination can be considered a criminal act resulting in sanctions, including fines and jail terms,${ }^{13}$ coercion is constrained by a desire not to undermine future public health campaigns 
and under pressure from international donors. ${ }^{14}$ Efforts have, therefore, focused on inducing compliance through persuasion (repeated visits and mobilizing community leaders), education (radio campaigns), carrots (e.g., lollipops for children), and soft sticks (social stigma and occasionally fines) ${ }^{15}$

Although there are high costs to coercion, there are low costs to bargaining with individual communities. The principal dynamics in Nigerian politics revolve around chains of patronage and the "sharing" of central government resources. The most common tactic used by politicians to mobilize political support is to promise individual or community benefits if elected. This typical way of doing business in Nigeria means that officials and politicians who engage in bargaining behavior during the polio campaign are not reprimanded or sanctioned.

\section{Citizens Can Withhold Compliance With Vaccination}

Despite the scale and intensity of the polio campaign, avoiding vaccination is relatively low cost. Although the campaign visits each household, parents have used a variety of evasion and foot-dragging techniques to prevent their children from receiving the vaccine. For example, parents can hide their children, bribe vaccinators to ink their child's finger without receiving the vaccine, or even take the vaccine on behalf of their child. ${ }^{16}$ Historically, large portions of the population have collectively resisted through organized religious networks. Of course, not all of these techniques will communicate a desire to bargain to the state, but the feasibility of noncompliance is clear. As described below, entire communities are also capable of preventing the work of vaccination teams. ${ }^{17}$

\section{Shared Preferences: Society Values Polio Vaccination}

The most important assumption required to differentiate the theory is that citizens overwhelmingly perceive polio vaccination as a desirable good and that compliance with the policy is, therefore, not costly. This has not always been the case in Nigeria. Historically, there has been deep suspicion about vaccination in certain communities. Over time, negative attitudes toward polio vaccination have been overcome and do not explain the most recent acts of noncompliance.

In mid-2003, an umbrella group for Nigerian Muslims purported that the polio vaccine could reduce fertility and cause AIDS (Obadare, 2005). After this pronouncement, three northern governors banned polio vaccination in their states, and two additional governors followed suit shortly thereafter. ${ }^{18}$ In the following years, the campaign invested in efforts to increase support 


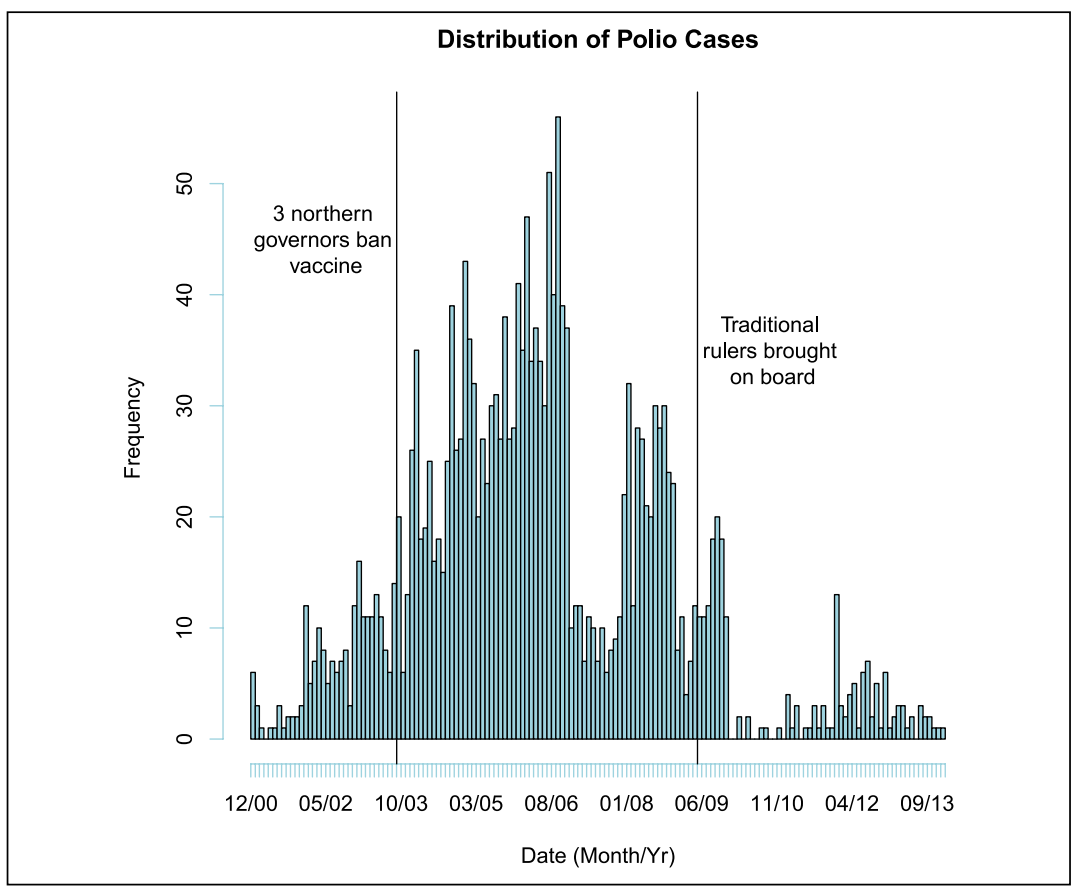

Figure I. Polio cases in Nigeria have dropped since 2009. This figure shows the frequency of polio cases from 2000 to 2013.

among the northern elite, such as sourcing the vaccine from Indonesia, a largely Muslim country (Ghinai, Willott, Dadari, \& Larson, 2013). In 2004, the bans were lifted.

A concerted government effort to reduce misinformation and integrate traditional leaders into the campaign succeeded in dramatically reducing fear around the vaccine. Over time, cases of polio have become increasingly rare and fell sharply when traditional rulers were brought on board in 2009 (Figure 1). ${ }^{19}$ Politicians have been incentivized, traditional leaders coopted and those spreading rumors isolated. A large infrastructure of information dissemination has been mobilized to counter rumors and suspicion using radio, fliers, town criers, and a viral campaign to share messages between phones using Bluetooth (National Primary Health Care Development Agency [NPHCDA], 2013; Renne, 2014). Figure 2 illustrates that in household-level monitoring data, the proportion of parents refusing to allow their children to be vaccinated is less than $1 \%$ since 2012 and household-level noncompliance continues to decrease over time. ${ }^{20}$ 


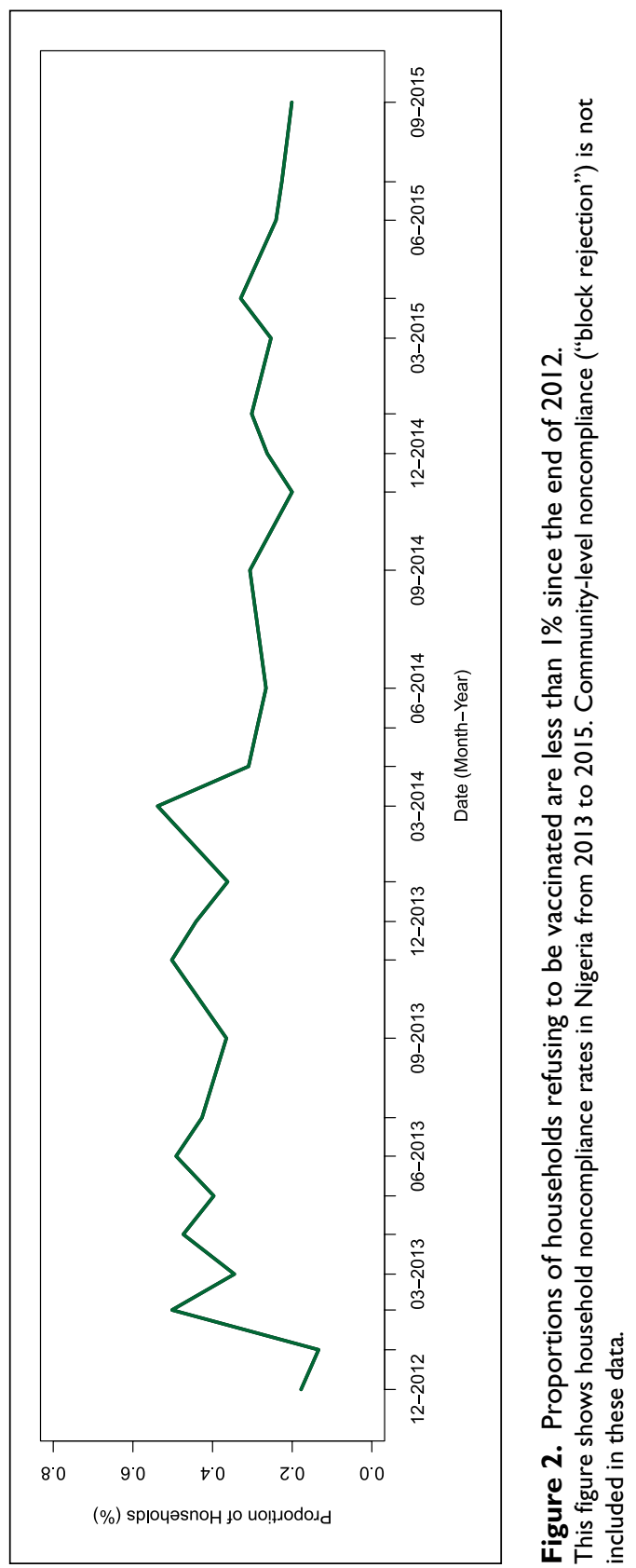






Figure 3. Self-reported reasons for household-level noncompliance, January 2013 to September 2015.

$\mathrm{OPV}=$ oral polio vaccine.

Even the few individual noncompliers are not frequently driven by concerns about the vaccination itself. Figure 3 shows the reasons given by parents who refuse to let their children be vaccinated. The figure reveals that even this household-level noncompliance is often associated with bargaining motives. For instance, citizens report that they have received no "pluses"incentives such as soap or sweets - or they complain that the vaccination has taken place over "too many rounds," or that local services have been neglected ("no felt need"). These reasons, indicated in Figure 3 by black bars, are consistent with our theory that citizens do value polio vaccination but value other policies more. In the remaining cases, among hundreds of thousands of successful immunizations, only a couple of thousand parents reported reasons consistent with a negative attitude toward the vaccine itself. ${ }^{21}$

Alongside minimal levels of individual noncompliance, a majority of citizens report that they value polio vaccination. Survey evidence collected by the Harvard Opinion Research Program (HORP) in $2014^{22}$ also points to the breadth of support for polio vaccination (Knowledge, Attitudes and Practices (KAPs) Polls in Pakistan and Nigeria, 2014). In Bauchi, Katsina, Sokoto, and Zamfara states, $97 \%$ of caregivers believe that giving polio drops to children is either a "very" or "somewhat" good idea. In Kano state, the same figure is $95 \% .{ }^{23}$ Only $4 \%$ of caregivers believe that a child does not need to take polio drops. An NPHCDA-U.S. Agency for International Development (USAID) survey reports that in very low-risk settlements, $99 \%$ of women and $97 \%$ of men approve of the vaccine. Even in very high-risk settlements, these figures are $93 \%$ and $91 \%$, respectively, indicating overwhelming support for the vaccine even in the most skeptical and adverse conditions. ${ }^{24}$ 


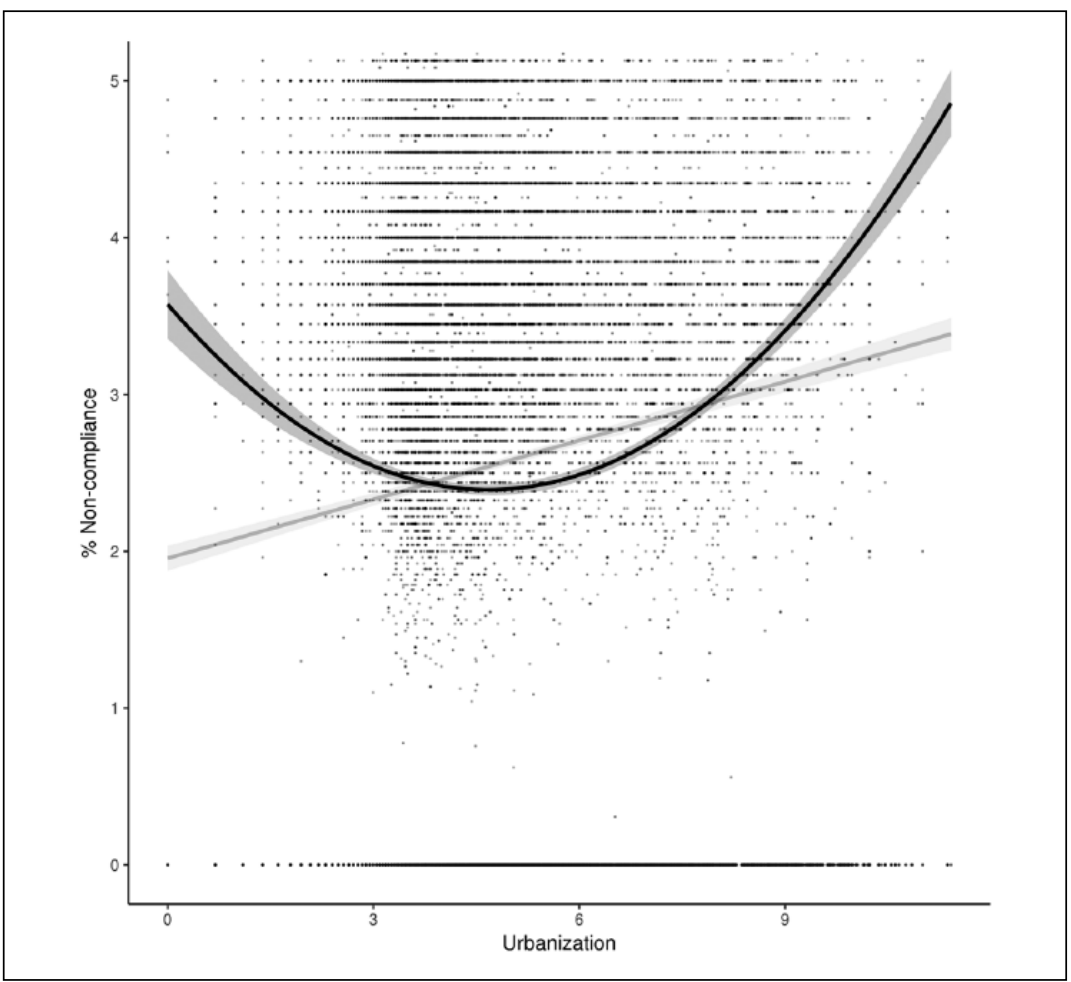

Figure 4. Noncompliance is highest in the most rural and the most urban areas. Ordinary least squares (OLS) line and Local Regression (LOESS) curves displayed. The figure shows household-level noncompliance only.

Noncompliance is also not linked with other predictors of bargaining power such as socioeconomic resources. Support for this claim comes from cross-referencing household-level noncompliance data we acquired from UNICEF $^{25}$ and geocoded ${ }^{26}$ population density data from Landscan, as illustrated in Figure 4. Noncompliance is most prevalent in both the most rural and most urban areas, suggesting a simple modernization story cannot account for the location of noncompliance.

\section{Shared Preferences: The State Values Polio Vaccination}

In contrast to widespread public service lapses, the policy attention and investment in the polio eradication campaign by the Nigerian government has been remarkable and unprecedented. Nigeria's status as one of just a 
handful of endemic countries for polio is a source of embarrassment for political leaders, and a major focus of the international community's pressure. The Presidency has repeatedly signed the Abuja Commitments, which pledge to eradicate polio by vaccinating at least $90 \%$ of children. At a 2011 Commonwealth meeting, then-President Goodluck Jonathan announced government investments of US\$60 million in polio eradication activities. As a sign of the scale of commitment, a Presidential Task Force was established in 2012. At its inauguration, President Jonathan stated,

I believe Nigerians that are here are as embarrassed as me whenever issues of polio are mentioned in the papers. That Nigeria is still a sanctuary of wild polio and we are becoming a threat to other countries ... It is quite embarrassing especially considering the fact that polio is a disease that we can conveniently eradicate ... My commitment to the people of this country is that between now and 2015 when my term of office is expected to end; we will work day and night to make sure that we eradicate polio. ${ }^{27}$

Although polio had not even registered in public debate during the elections, it quickly rose to the top of the Federal Government's agenda.

Beyond domestic commitment, the polio vaccination campaign in Nigeria is supported by hundreds of millions of dollars annually from the Bill and Melinda Gates Foundation, Rotary International, World Health Organisation (WHO), UNICEF, and various bilateral donors. ${ }^{28}$ These commitments have not simply been confined to discussions in the capital; the grassroots implementation is unrivaled in its intensity. Perhaps for the first time in history, the government is truly seeking to intervene in every village in the country with a policy. State governors compete over vaccination coverage in the Immunization Leadership Challenge, with prizes of US\$500,000 for additional public health projects of their choosing. Imams received intensive training on polio, which involved studying fatwas on vaccination and being given sermons they could adapt on disease prevention and health (Nasir et al., 2014).

These elite incentives create highly motivated politicians who want to reach universal compliance. Local government rapid response teams comprised of traditional, religious, and other local leaders stand ready during campaigns to respond to the various reasons a caregiver might provide for noncompliance. In one case where district officials were unable to resolve a case of community resistance, the local government chairman cut short a trip to Chicago and returned home to address the situation. ${ }^{29}$

Notably, state preferences are for a very particular structure of vaccination compliance. The polio vaccine requires high coverage to provide herd immunity, at least $80 \%$ and sometimes higher. The rewards for political leaders are 
discontinuous as their reputation is staked on the eradication of polio rather than simply its reduction. Crucially, the herd immunity dynamic must be replicated at the local level if it is to eradicate the virus - small pockets of even limited resistance, therefore, pose a major threat to the program's integrity. By contrast, provided that the rest of the village is vaccinated, the state does not care about a single individual who has not been vaccinated. Village-wide compliance rates sufficient to achieve herd immunity are the structure of compliance that policymakers value.

\section{The State Has a More Urgent Valuation of Polio Vaccination}

For threats to resist polio vaccination to be credible, society's positive valuation must be less urgent than the state's. There is strong evidence that this is the case. As argued above, polio commanded more public policy attention than virtually any other issue. Repeated targets and deadlines set by the international community created a sense of urgency in the government. By contrast, society's preferences were mild. Among the many livelihood challenges and health risks citizens face, polio is a low-ranking concern for most Nigerians. In the past 5 years as cases have declined to less than a few dozen annually, it has become very rare for citizens to see individuals in their communities with polio. The risk is perceived as very small, and is many orders of magnitude less of a threat to children than other high-profile killers such as malaria, diarrhea, and tuberculosis. Health conditions also frequently come second to infrastructure priorities. HORP researchers asked caregivers what the three most important issues faced by their neighborhood are that they would like government to address. In Kano state, health care was ranked third, with water access the top priority and energy access second. Citizens' lower valuation of polio vaccination contrasts strongly with the high profile it is accorded by the state.

\section{Citizens Know Polio Vaccination Is a State Priority}

The intensity of state efforts to implement polio vaccination does not go unnoticed by citizens who witness the announcements, logistics, and manpower involved. Several times each year, states coordinate 5-day vaccination campaigns, hiring hundreds of thousands of vaccinators with the goal of vaccinating every child below 5 years of age in the state. Vaccinated children have their thumbs inked, houses are marked with chalk codes to help ensure thorough coverage, and monitors visit a subset of communities to verify vaccinator reports by checking children's thumbs in a sample of households. These activities are all extremely visible. 
It is almost impossible for Nigerian citizens to avoid the communication campaign and the persuasive efforts of the state. According to UNICEF monitoring data (discussed in note 19), 95\% of respondents have heard about the immunization campaign before it arrives in their village. Even in a highly functioning state, this level of policy intensity would be a strong indication of state priority. Citizens observe intense government activity and understand that compliance with the polio vaccine is a government priority. That conclusion is even more striking when juxtaposed with the lack of attention paid to other public services. Yahya (2007) quotes a neighborhood security guard remarking,

If I go to the hospital, even simple panadol [paracetamol] for a headache, I cannot buy and these people are following us into our houses, forcing us to bring our children for free medicine for polio. What kind of humiliation is this? (p. 202)

In the Nigerian context, where public service delivery is generally weak and the state is frequently absent, the government's valuation of polio vaccination is self-evident.

\section{Evidence of Opportunistic Accountability}

Despite the desire for their children to be vaccinated against polio, Nigerians have frequently resisted the vaccine through community-wide acts of "block rejection." Examining all known cases of block rejection, we confirm that the motivation was "opportunistic," aiming to initiate bargaining on policy issues unrelated to polio vaccination, in almost all instances. We establish that, in contrast to household-level noncompliance captured in the UNICEF data, block rejection at the village level is empirically common. The outcomes of block rejection also indicate that the bargaining power block rejection provides is substantial and frequently leads the state to accede to community demands. Our analysis is not intended to explain why some communities conduct block rejection and others do not. Rather, the objective is to use the administrative data and case studies to investigate whether communities' motivations and behavior in conducting block rejection are consistent with the theory of opportunistic accountability.

Obtaining data on cases of block rejection was not straightforward. Block rejection data are not collected systematically at the state or national level. Although the household-level monitoring data are collected in villages after each round of polio vaccination, monitoring teams do not collect data in block rejection villages, believing that they will not provide new information. 
Data on community-wide block rejection are, therefore, completely censored from the household-level data. Accordingly, we made extensive efforts to acquire data on block rejection in one local government in Kaduna state (Giwa local government), along with data from one entire state, Kano. This case selection was meant to enable an understanding of how noncompliance is used in the contexts where it is most common and was not intended to be fully representative of northern Nigeria. Within Giwa, we worked closely with the local polio team to obtain a record of all block rejection cases in the 4 months between January and April 2015. For Kano, we obtained data collected by the state polio campaign coordinators on the universe of block rejection cases between April and December 2015.

\section{Motives for Noncompliance}

Table 1 shows the universe of block rejection cases in Giwa local government between January and April 2015. Table 2 shows the universe of block rejection cases in Kano state between April and December 2015. With only one exception - a village in Giwa that did block rejection because they felt they had received too many rounds of the vaccine - all other known reasons for block rejection pertain to concerns wholly unrelated to vaccination. Instead, communities demanded public support on issues such as public goods or dispute resolution. These are clear cases where the community was resisting not because of any direct concerns about the vaccine, but instrumentally and opportunistically to gain concessions. Moreover, in contrast with the household-level data, where resistance motivated by concerns about the vaccine is vanishingly small at well below $1 \%$ of households, the incidence of block rejection in these regions is extremely high. In Giwa, we were unable to locate a single village that had not engaged in block rejection at some point in time. The prevalence of community-wide block rejection is consistent with the level at which noncompliance imposes meaningful costs on the state and produces a bargaining opportunity for citizens. Figure 5 provides evidence of how concerns are communicated and justified within a community to motivate collective action. ${ }^{30}$

\section{Evidence From Cases of Successful Bargaining}

In this section, we illustrate the process of opportunistic accountability by considering in more depth two communities in Giwa that have done block rejection. A Giwa local government consultant helped us identify these villages by thinking about areas that have had high rates of noncompliance with polio vaccination. These two communities are not intended to be 
Table I. Known Cases of Block Rejection in Giwa Local Government, Kaduna State, Between January and April 2015.

\begin{tabular}{|c|c|c|c|}
\hline Settlement & Ward & Date & Reason for block rejection \\
\hline Jangefe & Danmahauwayi & January 2015 & Dilapidated primary school \\
\hline Madugu & Galadimawa & January 2015 & Dilapidated primary school \\
\hline Tunga & Gangara & January 2015 & No good road \\
\hline $\begin{array}{l}\text { Anguwan Hassan } \\
\text { F.C }\end{array}$ & Gangara & January 2015 & $\begin{array}{l}\text { Health facility and dilapidated } \\
\text { primary school }\end{array}$ \\
\hline Tashan Dundu & Giwa & January 2015 & Electricity \\
\hline Hayin Maje & Giwa & January 2015 & Unknown \\
\hline Tudun Wada “A” & Giwa & January 2015 & Unknown \\
\hline Rugubawa & Wazata & January 2015 & $\begin{array}{l}\text { Community member's goat } \\
\text { stolen }\end{array}$ \\
\hline Ganga & Kakangi & January 2015 & Dilapidated primary school \\
\hline Ang. Jola & Shika & January 2015 & No good road \\
\hline Tsibirin lya & Shika & January 2015 & Dilapidated primary school \\
\hline Ang. Loko & Idasu & January 2015 & Too many rounds \\
\hline Melawa & Galadimawa & $\begin{array}{l}\text { January } 2015, \\
\text { March } 2015 \\
\text { April } 2015\end{array}$ & $\begin{array}{l}\text { Football field, Hausa-Fulani } \\
\text { conflict }\end{array}$ \\
\hline Anguwan Waziri & Galadimawa & January 2015 & $\begin{array}{l}\text { Social amenities in } \\
\text { community }\end{array}$ \\
\hline Kaza-Karama & Idasu & January 2015 & $\begin{array}{l}\text { Health facility and dilapidated } \\
\text { primary school }\end{array}$ \\
\hline Anguwan Dankuda & Kakangi & January 2015 & No road, primary school \\
\hline Dokan Yau & Yakawada & January 2015 & No road, primary school \\
\hline Anguwan Illo & Yakawada & January 2015 & No road, primary school \\
\hline Anguwan Wadatan & Yakawada & January 2015 & No road, primary school \\
\hline Turunkawa & Idasu & March 2015 & Net-card not provided \\
\hline Yantukwane & Idasu & March 2015 & No mono pump \\
\hline Bataron Kanhanya & Idasu & March 2015 & Electricity and schools \\
\hline Pandogari & Giwa & April 2015 & Social amenities \\
\hline Anguwan Rimi & Giwa & April 2015 & $\begin{array}{l}\text { Mosquito nets not } \\
\text { distributed }\end{array}$ \\
\hline Kakangi Gari & Kakangi & April 2015 & Social amenities \\
\hline Dokan Danmagaji & Kakangi & April 2015 & Social amenities \\
\hline Rugan musa PRP & Kakangi & April 2015 & Social amenities \\
\hline Gidan Goji & Kakangi & April 2015 & Social amenities \\
\hline Unguwan Bazariya & Kakangi & April 2015 & Social amenities \\
\hline Gogin Liman & Kidandan & April 2015 & $\begin{array}{l}\text { Mosquito net distribution } \\
\text { and commenced building of } \\
\text { health clinic but stopped at } \\
\text { foundation level }\end{array}$ \\
\hline
\end{tabular}


Table 2. Known Cases of Block Rejection in Kano State Between April and December 2015.

\begin{tabular}{|c|c|c|c|}
\hline Settlement & Ward & Date & $\begin{array}{l}\text { Reason for block } \\
\text { rejection }\end{array}$ \\
\hline Gidan Rijau & Kumurya & April 2015 & Net distribution \\
\hline Gadama (Gidan Biri) & Kumurya & April 2015 & Net distribution \\
\hline Makadawa & Kumurya & April 2015 & Net distribution \\
\hline Gidan Agalawa & Kumurya & April 2015 & Net distribution \\
\hline Unguwa Uku & Kumurya & April 2015 & Net distribution \\
\hline Masari & Kumurya & April 2015 & Net distribution \\
\hline Ugunwar Kiyashi & Gafan & April 2015 & Net distribution \\
\hline Makuntari Gidan Liman & Gafan & April 2015 & Net distribution \\
\hline Gafan B/Gwadabe & Gafan & April 2015 & Net distribution \\
\hline Batutawa Takun Alsasawa & Gafan & April 2015 & Net distribution \\
\hline $\begin{array}{l}\text { TFulani G/Gidan Auduga } \\
\text { Mahauta }\end{array}$ & Gafan & April 2015 & Net distribution \\
\hline Binkau Gidan Liman & Gafan & April 2015 & Net distribution \\
\hline Katsinawa & Gurjiya & April 2015 & Net distribution \\
\hline Mabuga & Gurjiya & April 2015 & Net distribution \\
\hline Gidan Gwani & Gurjiya & April 2015 & Net distribution \\
\hline Kanbaiwa & Gurjiya & April 2015 & Net distribution \\
\hline Ziyara Yamma & Gediya & April 2015 & Net distribution \\
\hline Gidan Mal Ahmadu & Gediya & April 2015 & Net distribution \\
\hline Gidan Magari & Gani & April 2015 & Net distribution \\
\hline Gidan Maina & Gani & April 2015 & Net distribution \\
\hline Zamba Arewa & Sitti & April 2015 & Net distribution \\
\hline Dangazangar & Sitti & April 2015 & Net distribution \\
\hline Sanda Katrijai & Sitti & April 2015 & Net distribution \\
\hline Gidan Fatumal & Sitti & April 2015 & Net distribution \\
\hline Dagora & Massu & April 2015 & Net distribution \\
\hline Lumawa & Massu & April 2015 & Net distribution \\
\hline Massu Cikin Gari & Massu & April 2015 & Net distribution \\
\hline Labunawan Kanawa & Baburi & June 2015 & Net distribution \\
\hline Yammawa & Baburi & June 2015 & Net distribution \\
\hline G/lyakai & Baburi & June 2015 & Net distribution \\
\hline Asayaya & $\begin{array}{l}\text { Burum } \\
\text { Bburum }\end{array}$ & June 2015 & Net distribution \\
\hline Gidan Madori & Dalawa & July 2015 & Repair of well \\
\hline Kanyi & Baburi & July 2015 & Net distribution \\
\hline Karshi Cikin Gari & Zoza & $\begin{array}{l}\text { October and } \\
\text { December } 2015\end{array}$ & $\begin{array}{l}\text { Turbaning of } \\
\text { traditional ruler }\end{array}$ \\
\hline
\end{tabular}


Table 2. (continued)

\begin{tabular}{|c|c|c|c|}
\hline Settlement & Ward & Date & $\begin{array}{l}\text { Reason for block } \\
\text { rejection }\end{array}$ \\
\hline Gidan Bajida & Zoza & October 2015 & $\begin{array}{l}\text { Turbaning of } \\
\text { traditional ruler }\end{array}$ \\
\hline Gidan EE & Zoza & October 2015 & $\begin{array}{l}\text { Turbaning of } \\
\text { traditional ruler }\end{array}$ \\
\hline Gidan Baki & Zoza & $\begin{array}{l}\text { October and } \\
\text { December } 2015\end{array}$ & $\begin{array}{l}\text { Turbaning of } \\
\text { traditional ruler }\end{array}$ \\
\hline Unguwar Jakada & Zoza & October 2015 & $\begin{array}{l}\text { Turbaning of } \\
\text { traditional ruler }\end{array}$ \\
\hline Gidan Bukka & Zoza & $\begin{array}{l}\text { October and } \\
\text { December } 2015\end{array}$ & $\begin{array}{l}\text { Turbaning of } \\
\text { traditional ruler }\end{array}$ \\
\hline Gidan Tsoro & Zoza & $\begin{array}{l}\text { October and } \\
\text { December } 2015\end{array}$ & $\begin{array}{l}\text { Turbaning of } \\
\text { traditional ruler }\end{array}$ \\
\hline Gidan Galo & Zoza & $\begin{array}{l}\text { October and } \\
\text { December } 2015\end{array}$ & $\begin{array}{l}\text { Turbaning of } \\
\text { traditional ruler }\end{array}$ \\
\hline Kwakwan & Zoza & December 2015 & $\begin{array}{l}\text { Turbaning of } \\
\text { traditional ruler }\end{array}$ \\
\hline Gidan Bawa & Zoza & December 2015 & $\begin{array}{l}\text { Turbaning of } \\
\text { traditional ruler }\end{array}$ \\
\hline Unguwar Nashakar & Zoza & December 2015 & $\begin{array}{l}\text { Turbaning of } \\
\text { traditional ruler }\end{array}$ \\
\hline
\end{tabular}

In this table, "net distribution" references frustration among communities that were not provided with mosquito nets during a distribution campaign. The same people who distributed the nets as part of a Roll Back Malaria campaign were used on the polio vaccination campaign, so villagers saw polio block rejection as an appropriate tool to get their complaints heard. Ultimately, local governments provided the communities with mosquito nets. "Turbaning of traditional ruler" references frustration among communities over a new local leader who was selected by higher up traditional leaders, but who was not the locally desired candidate.

representative of all communities in northern Nigeria, though individuals involved in the polio vaccination campaign report that they are not unique. We use these cases purposefully to more fully establish whether the community behavior amounted to a pattern of bargaining. We show that it did, and that it has been successful in producing a meaningful response from government. We also use the cases to confirm assumptions of the theory, namely, that compliance need not be costly and that citizens know the policy is a priority to the government. ${ }^{31}$

Block rejection in Unguwa Lalle. Unguwa Lalle is a farming village with about 1,750 residents. It is a $5 \mathrm{~km}$ drive from the town of Giwa. Up until the polio 


\section{ol 10 STOP! POLIO STO}



Mutanan yankin Dakata, Dawaki, Zango, yadakunya (Bela)

da Kauyukan su. Bazamu sake karbar allurar Polio ba.

Dalilai muna cikin bacin rai saboda rashin hanya. A sakamakon rashin Hanya ta. Sakamakon Rashin hanya ta hayfar da

1. Babu Hanyar Ruwan sama

2. Ruwa Yanayi mana barna a Gidajenmu

3. Rashin hanyar Mota, wanda yana Hana zuwa Asibiti da kuma wahalar zuwa aiki, Gona, Makaranta da sauransu.

Akan wannan da dalilai mun Gamsu cewa Gwamnati bata damu da Halin da Muke ciki ba sai dai kawai Polio akeyi mana. To!!! Bazamu sake Karba Allurar Polio ba.

Figure 5. A poster used to coordinate resistance to vaccination in a peri-urban area of Kano.

The poster states: "People of the area of Dakata, Dawaki, Zango, Yadakunya (Bela), and their villages. We will never again accept the Polio vaccinations. Because we are angry due to the lack of roads. Lack of roads has caused the following: I. There is no drainage for the rain, 2 . Rain is destroying our houses, 3 . Lack of roads for our vehicles, which prevents us from going to the hospital and causes us difficulties in going to work, the farm, school, and other places. Because of these reasons, we are convinced that the government does not care about the conditions that we are in, they are only interested in polio. Well! We will never again accept the Polio vaccinations." 
vaccination campaign became intense, Unguwa Lalle's story was largely one of having requests for government services go unheeded. As an example, a bridge connecting the primary school to the village had been in poor condition for years. The village repeatedly requested that the local government fix it, with no success. Ultimately, the community fixed the bridge itself in 2005.

It was not until the peak of the polio vaccination campaign that the community experienced a link between making a request and the government responding. Around 2008, frustration in Unguwa Lalle had been rising around the issue of electricity. A village just $2 \mathrm{~km}$ away had electricity, but Unguwa Lalle did not. To make matters worse, the government had asked Unguwa Lalle residents to help install electricity in this nearby village, promising that they soon would receive electricity as well. The residents assisted, but the government did not fulfill its promise. Unguwa Lalle repeatedly requested electricity, including by writing formal letters of request, as they had been instructed to do. Still, electricity was not provided.

Around this time, polio vaccinators had been coming to the village with increasing frequency. ${ }^{32}$ In a context where receiving any sort of visit from government officials was rare-over the past 4 years, the only nonvaccination-related government visit the community could recall was a single visit from a state senatorial candidate in 2015-it was fairly straightforward to determine that the government valued compliance. "To us honestly we just saw that the government takes more priority of polio than the needs of the community," one villager said. ${ }^{33}$

Some years earlier, residents had been suspicious of the vaccine. But they now welcome it. A 35-year-old man said residents previously thought the vaccine was "a way of bringing chaos to the community, that it had been brought [to their community] to [both] vaccinate our children and stop the children from giving birth in the future." Following sensitization efforts, however, these concerns dissipated: "polio and the polio vaccine . . became clear," he said. "We now understand the concept of it. We are well-informed with not any suspicions about it." 34 "To us the government is really trying to invest much in eradicating polio. We believe they are doing a very good job," a villager said..$^{35}$ They believe, "the disease is very serious and can harm our children if proper care is not taken."

Despite a desire for their children to be vaccinated against polio, villagers decided to resist when polio vaccinators visited them around 2010. One Unguwa Lalle leader put it best: "Seeing the opportunity of the vaccination campaign, we decided to take advantage of it." ${ }^{36}$ The entire community refused to allow vaccinators to vaccinate their children. At this time, vaccination campaigns were occurring every 3 months. The community refused to allow vaccinators into the community for over a year-five rounds of the vaccination campaign. 
There was overwhelming support from the community to engage in block rejection. When asked whether anyone in the village did not want to go along with the block rejection, one villager reported that everyone supported it. "No one had been skeptical about doing it. We believe this is democracy and we have the right to demand what we really need, which will benefit the whole village not just one individual." 37

The state's response to this sustained noncompliance was substantial. A local emir came to the village to discuss the matter with the entire community. The deputy governor and his wife visited the village. Remarkably, in 2011, and for the first time ever, the Kaduna State Governor visited the community, meeting with the village head and ordinary villagers face to face. $\mathrm{He}$ promised to bring electricity to the community.

Following the governor's visit and promise of electricity provision, the community allowed vaccinators access to their children. This time, the government fulfilled their end of the bargain. The local government chairman sent trucks carrying poles and wires to the village, but the poles and wires needed to be set up and a transformer provided. It took an additional year and another round of block rejection to receive the transformer. A local government official who was involved in this process confirmed that the transformer was also supplied in response to the community's block rejection. ${ }^{38}$ As of writing, Unguwa Lalle has functioning electricity, 10 years after the nearby village got it, and has never again engaged in block rejection. Block rejection empowered community members to achieve these results.

Although the post-block rejection delays in electrification would seem frustrating, Unguwa Lalle residents are now fairly satisfied with their relationship with the government. According to the village head, "We really do perceive the government very well because when we forward an issue now the issue easily gets resolved." "[Though the road] is not tarred it is better than before," one villager said. "We have electricity and borehole for the whole community. At least that's enough for now and probably later in the future we request for other important things to bring development to this community."

Unguwa Lalle demonstrates that by collectively refusing polio vaccination - even though residents valued vaccination - the community managed to gain extraordinary attention from the government. We document the direct connection between these efforts and the process through which opportunistic accountability occurred and the community received electricity.

Block rejection in Turawa. Turawa is a town $11 \mathrm{~km}$ from Giwa town, with around 8,000 residents. Most residents are farmers. Prior to the intensification of the polio vaccination campaign, Turawa had had slightly more success than Unguwa Lalle in making demands on the government. But still, the 
community's two main priorities—road improvement and electricity—had not been addressed adequately.

Turawa had seen other communities successfully use block rejection, and so they decided to try it themselves. In an attempt to draw the government's attention to the community's concern about the road, Turawa collectively refused polio vaccination for a period of 3 months in 2002. Block rejection successfully attracted the attention of the local government. Following these 3 months of sustained collective refusal, the district head, a local government director, and a polio vaccination campaign leader summoned the former village head to meet and discuss the noncompliance. At the meeting, the local government agreed to forward the road construction request to the state government. "The [local government] promised to fulfill their end and asked the community in return to stay in peace with anyone visiting the community, especially in terms of dealing with health issues, and always be patient," one villager said. ${ }^{41}$

Ultimately, it was determined that it would be difficult to get funding to improve the road, but that funding had been allocated to provide electricity and that the implementation of that process could be expedited. This - at least temporarily - satisfied the community. As in Unguwa Lalle, the process of getting functioning electricity was slow. First poles and wires were brought. The transformer followed 2 years later, and lay uninstalled for 3 months. After eventually being installed, the transformer worked for 6 months before it started having problems. Turawa villagers asked the government to repair the transformer, and their federal senator assisted with forwarding on the request.

After 3 weeks, people arrived to take away the malfunctioning transformer. They tried to convince the community that they would bring a new one, but the residents believed that if the broken transformer was removed, they might never have power again. So, the residents quickly came up with the idea to prevent the company from removing the damaged one until they brought the new one. Turawa residents also decided that they would get an expert to install and verify the new one before the company could collect the damaged one. This plan worked, and eventually, they had a functioning transformer.

After numerous requests from the community, the government ultimately tarred the road leading to the village. It is possible that block rejection credibly signaled to the government the community's capacity and willingness to do it again. The road may have been improved as a strategy to preempt future noncompliance, though we cannot say this with certainty.

Today, Turawa residents view the government positively. "Whenever we request something from the government they seem to respond to it averagely ok," a 26-year-old Turawa resident said. ${ }^{42}$ Although Turawa had had some prior success in making claims on the government, they opportunistically 
used block rejection as a strategy to complement their other tools of accountability and obtain one of their most desired services: electricity.

Health camps. In another important way, polio vaccination in northern Nigeria has strengthened the social contract between the state and its citizens. As advocated by Levi (1989), and as extensively practiced in the fiscal case, the state has begun to preempt noncompliance motivated by bargaining by providing a broader range of goods that citizens value more than polio vaccination. These offerings have moved beyond transactional "bribes" in the form of sweets or bars of soap, to the systematic provision of health camps in areas with high rates of noncompliance. Health camps - where health professionals visit a village for a day-provide access to a range of medical diagnoses and treatments for conditions that are much more common and for which local health services are inadequate (Desmarais, 2016; EOC Nigeria, 2015). The expensive rollout of health camps was explicitly motivated by the desire to tackle noncompliance with polio vaccination:

House-to-house polio vaccination campaigns breed contempt in communities that are not served with other needed primary health care services ... Health Camps are created in non-compliant communities to surge demand and uptake of OPV [oral polio vaccine] and other RI antigens by bundling (the vaccines) with Primary Health Care interventions with greater appeal to the targeted communities. (EOC Nigeria, 2015, p. 3)

Health camps appear to be preempting block rejection both in Unguwa Lalle and Turawa. In both communities, villagers report health camps as being even more frequent than vaccination rounds; the health camps are roughly every month, or every other month. To provide a sense of the scale, in 2014, the Kano State Government was providing 2,000 health camps each month. ${ }^{43}$ In short, the threat of noncompliance appears to have become institutionalized and generated an equilibrium of government service provision and societal compliance, evidence of a social contract.

\section{Conclusion}

In contexts where citizens lack common forms of social power, such as effective elections or the ability to withhold taxes, the prospects for accountability are generally considered weak. This study has argued that there may be alternative pathways to accountability where the state and society share common interests. The source of society's bargaining power is that the state values the policy relatively more and is more impatient for it to be implemented, making it vulnerable to delaying tactics. As the case studies illustrate, during Nigeria's 
polio campaign, some communities managed to extract substantial concessions from the state on other policy issues through noncompliance, even when they had no concerns about the vaccine itself. Recognizing their newly acquired tool to frustrate the state's objectives and bargain, these communities have taken an innovative and opportunistic route toward greater government accountability.

By expanding the range of policies that are capable of stimulating a social contract, we have suggested that social contracts may be feasible in otherwise adverse conditions, specifically in nondemocratic, rentier, or aiddependent states. Where the top-down and international pressures to deliver a variety of public services are increasing, there are likely to be a wealth of new opportunities for citizens to extract concessions from the state. Although the delivery of international aid has often been argued to undermine domestic accountability (Burchardt, Patterson, \& Rasmussen, 2013), we highlight a role for international pressure in enhancing accountability to local communities by aligning the intrinsic preferences of elites with those of their societies. ${ }^{44}$

There are also important limits to the opportunistic accountability dynamic. Some policies - national monetary policy, for example - may simply not provide opportunities for citizen noncompliance. Other policies may be too valuable for citizens to forgo, such as famine relief or emergency health care. Even where citizens are willing and able to use noncompliance opportunistically, the responsiveness of the state is hard to predict. Its willingness to make concessions will depend on the precise contours of its own valuation of compliance and the information society has available. The prospects of success will depend on an entrepreneurial leader who can recognize the structure of the bargaining opportunity and mobilize collective action. Finally, the sustainability of the social contract will depend on how long the state remains interested in the policy.

Nonetheless, states may find it difficult to escape the constraint of opportunistic accountability. Unlike the taxation case, efforts to increase enforcement as an alternative to bargaining may backfire if they serve only to highlight the intensity of the state's desire for compliance. As the Nigerian polio campaign illustrates, the incongruity of intense policy implementation against a backdrop of public service neglect provides a clear signal that the state's structure of preferences favors bargaining. Disbursing more rounds of polio vaccination simply reinforced this signal and provided additional bargaining opportunities. This suggests that state-led efforts to implement policies that citizens value are not passively received by citizens. These policies create unanticipated windows of opportunity that empower citizens with bargaining strategies that can generate new channels of broader accountability. The roots of the social contract do not, then, need to be anchored in conflict between state and society but may also be found amid shared policy goals. 
This study has illustrated how opportunistic accountability can play out, but we propose three important areas for future research. First, variation over space or time in the state's valuation of a common-interest policy should produce systematic variation in communities' ability to successfully demand other public benefits. Quantitative analysis should be able to detect this variation and provide further evidence of the importance of the mechanism, for example, through the use of a geographic regression discontinuity where state preferences change sharply over space. ${ }^{45}$ Second, when all communities have the latent power to resist a policy and make demands on the state, what explains variation in the use of this strategy? Third, as of writing, the Nigerian government still highly values polio eradication. It is difficult to predict what will happen when priorities change. Are these nascent social contracts somehow sustained? Or does government neglect return as soon as the policy recedes in importance?

\section{Acknowledgments}

Thanks to UNICEF, WHO, NPHCDA, Gates Foundation, eHealth Africa and Harvard Opinion Research Polling. Special thanks to Tasui Abubakar, Musa Abdullah Bala, Melissa Corkum, Abashe Gandu, Dr. Benjamin Gugong, Lea Hegg, Gerida Joseph, Evan Lieberman, Noah Mataruse, Gwyneth McClendon, Godfrey Musuka, Ugochukwu Nwakile, Mohammad Saad, Abubakar Shehu, Adam Thompson, Kebba Touray, Lily Tsai, and Yuhua Wang for their valuable input, and to John Marshall for comments on an earlier version of the online appendix. Interviews for this project were approved by Harvard University's Committee on the Use of Human Subjects, IRB \#14-0871.

\section{Declaration of Conflicting Interests}

The authors declared no potential conflicts of interest with respect to the research, authorship, and/or publication of this article.

\section{Funding}

The authors received no financial support for the research, authorship, and/or publication of this article.

\section{Supplemental Material}

Supplementary material for this article is available online at the CPS website http:// journals.sagepub.com/doi/suppl/10.1177/0010414017720706.

\section{Notes}

1. http://www.indiaenvironmentportal.org.in/content/228092/villagers-boycottpulse-polio/

2. http://www.ndtv.com/india-news/fifteen-villages-boycott-polio-vaccination-inbihar-478565 
3. http://www.thestatesman.com/mobi/news/india/local-issues-take-a-toll-onimmunisation-drive-in-up-district/61436.html\#XsMkFPz2217Cf2W8.99

4. http://www.rferl.org/content/polio-eradication-pakistan-electricity-politics/ 25012852.html

5. http://www.economist.com/news/middle-east-and-africa/21702471-thousandssyrians-are-trapped-border-jordan-haven-hell? $\mathrm{frsc}=\mathrm{dg} \% 7 \mathrm{Cd}$

6. Both models use the equilibrium concept of subgame perfect Nash equilibrium.

7. Alternative accountability processes also highlight opportunities where the state makes itself vulnerable through policy choices. Distelhorst (2015) illustrates how the introduction of institutions for government responsiveness - and, in particular, the failure of these institutions to achieve their stated aims - creates opportunities for individuals to make claims on the state. O'Brien and Li (2006) argue that where certain elites share interests with citizens, for example, the desire to tackle corruption, this alliance can be particularly effective at extracting accountability from other parts of the state through "rightful resistance." In contexts where collective mobilization is risky, $\mathrm{Fu}$ (2016) shows how civil society groups covertly coach individual citizens to make demands on the state by appealing to a bureaucrat's "mandate," similar to what Zhou (1993) calls "collective inaction." Finally, Tsai (2015) describes "constructive non-compliance," where citizens resist a policy as a strategy to communicate priorities vis-à-vis that policy to the government.

8. In the terminology of economics, the state's relatively greater valuation affects both the extensive margin (the state's willingness to bargain at all) and the intensive margin (the degree of accountability society can extract from the state).

9. Acts of noncompliance become even more probable when the state's valuation of the policy is not static, as we might expect with constantly shifting domestic and international policy priorities.

10. Studies of coproduction illustrate the range of activities that the state and society jointly value and must jointly agree on.

11. For example, in the former USSR, elites' preferences for impressive but superficial elections afforded citizens narrow opportunities to bargain with the state for services. When mandated party officials would go door to door to register voters, citizens would "refuse to register when visited by a canvasser in the hope of having him report to his supervisors dissatisfaction with unpaved roads, leaky roofs and the like" (Zaslavsky \& Brym, 1978, p. 367). What elites intrinsically valued - turnout - could be used as a tool to make them more responsive.

12. In defining state preferences, it is important to take into account that the state may have relationships with many societal actors and is able to substitute policy implementation between them to meet its goals. This will reduce societal bargaining power. However, where the state requires compliance from specific communities (or a high overall rate of compliance), there is less scope for substituting its implementation efforts away from the communities best able to resist. We thank an anonymous reviewer for highlighting this point.

13. This varies by state. See, for example, http://allafrica.com/stories/201309240197. html

14. http://www.ghjournal.org/sehat-ka-insaf-a-model-for-overcoming-polio-inpakistan/ 
15. Although low-level selective intimidation was used during the peak of opposition some years ago (Renne, 2014), this has become rare and was restricted to pressuring elites that organized opposition to the campaign or actively spread rumors.

16. Interview with Aminu Gamawa, a Nigerian barrister who has conducted research on noncompliance with polio vaccination, on October 20, 2014.

17. It is beyond the scope of our analysis to examine variation in successful collective action, which will be affected by the range of factors highlighted by Olson (1965) and others.

18. These concerns, although scientifically unfounded, did not emerge in a vacuum. In 1996, Pfizer had tested Trovan, a meningitis drug, on children in Kano without approval from the Nigerian government (see: http://www.washingtonpost.com/ wp-dyn/content/article/2006/05/06/AR2006050601338.html). Several children who received Trovan suffered brain damage and died. These cases exacerbated suspicion of free Western drugs. Nigeria had emerged from military rule 4 years prior to the Pfizer scandal and the first civilian president, Olusegun Obasanjo, was a southerner who won reelection by defeating a northern candidate. Fraught north-south relations worsened suspicion over the vaccine, which in addition to being seen as an international campaign was also seen as a federal campaign (Obadare, 2005).

19. UNICEF sends monitors to settlements following vaccination rounds to survey 15 randomly sampled households. The monitoring data set records the number of unvaccinated children and total number of children in these 15 households. The data cover roughly 80,000 settlements between December 2012 and September 2015 (data from July and August 2015 are missing).

20. These data do not include collective noncompliance-_block rejection"-for administrative reasons discussed further in the section "Evidence of Opportunistic Accountability."

21. We acknowledge that parents may be reluctant to respond truthfully to this question, but given that they have already refused vaccination, it is unclear what would bias their responses. None of the justifications would be acceptable to the government.

22. This was a representative survey of 2,629 individuals in six high-risk states in northern Nigeria: Bauchi, Borno, Kano, Katsina, Sokoto, and Zamfara.

23. Only in Borno state was the figure noticeably lower at $88 \%$. This is likely explained by the challenges of policy implementation amid the Boko Haram conflict.

24. Page 21 of https://www.comminit.com/files/perceptionsofinfluence.pdf

25. These data are discussed in note 19 .

26. We took the following steps to georeference the monitoring data. First, we collaborated with eHealth Africa, which employs experts in geocoding, fuzzy matching, and the local Hausa language. Second, because this coding process is labor intensive and ongoing, we also draw on the Nigerian National Population Commission's register of settlements. We use a fuzzy matching algorithm with a low tolerance for deviations to match settlements by name that are known to be in the same state, local government, and ward. These two strategies enable us to confidently match $44 \%$ of the settlements. (All figures in this article, then, use data from at least 
35,000 settlements.) On one hand, this suggests there may be a selection bias to the villages we can geocode. Indeed, a comparison of rates of resistance suggests that our geocoded sample is biased to marginally underestimate noncompliance $(2.5 \%$ vs. $2.8 \%$ in the nongeocoded sample on our broadest definition of noncompliance). On the other hand, the full data set is itself a nonrandom sample of villages and our remaining data still cover large portions of the country.

27. http://www.premiumtimesng.com/regional/nnorth-east/4032-president_inaugurates_task_force_on_polio.html

28. Financing information can be found here: http://polioeradication.org/financing/ expenditure-information/annual-expenditure-reports/

29. Interview with UNICEF consultant, September 22, 2014

30. Where society values a policy, organizing to deny members the benefits of the policy is likely to pose a particularly acute collective action problem. The standard free-rider challenge is heightened when each individual has an active incentive to defect and receive the benefit of the shared-interest policy, while relying on others to pressure for any bargaining gains. The difference is, however, one of degree rather than kind and the many successful cases of block rejection are testament to the power of the opportunistic accountability motive.

31. Musa Abdullah Bala, our research assistant, conducted the interviews that follow in May and June 2015, and in February and March 2017. Bala conducted the interviews in Hausa and then translated them into English. In each community, Bala spoke with both community leaders and ordinary residents.

32. Funding for the polio campaign increased substantially from 2009 when a new strategy was adopted. To provide a rough sense of the intensity, between 2013 and 2016 the village received about 20 visits from vaccine campaign staff working to sensitize villagers to the purpose of the vaccine, along with more than 20 additional visits from actual vaccinators. These figures are estimates by Unguwa Lalle residents and are consistent with the campaign schedule.

33. Interview on February 21, 2017.

34. Interview on June 1, 2015.

35. Interview on February 21, 2017.

36. Interview on June 1, 2015.

37. Interview on February 21, 2017.

38. Interview on March 11, 2017.

39. Interview on June 1, 2015.

40. Interview on February 21, 2017.

41. Interview on February 25, 2017.

42. Interview on May 26, 2015.

43. https://www.youtube.com/watch? $\mathrm{v}=\operatorname{LrgfokfOA} 5 \mathrm{k}$

44. This may involve persuasion or simply incentive schemes and social networks that select for performance on policies that local society values.

45. Our efforts to conduct such an analysis for the Nigerian case were hampered by data availability and methodological challenges to inference. In particular, geographic discontinuities were confounded by the effects of coincident administrative borders that also shaped broader accountability. 


\section{References}

Avery, C., \& Zemsky, P. B. (1994). Money burning and multiple equilibria in bargaining. Games and Economic Behavior, 7, 154-168.

Burchardt, M., Patterson, A. S., \& Rasmussen, L. M. (2013). The politics and antipolitics of social movements: Religion and HIV/AIDS in Africa. Canadian Journal of African Studies, 47, 171-185.

Clark, W. R., Golder, M., \& Golder, S. (2017). An exit, voice, and loyalty model of politics. British Journal of Political Science.

Desmarais, S. (2016). Eradicating polio in Nigeria (Tech. Rep.). McKinsey. Retrieved from http://www.mckinsey.com/industries/healthcare-systems-and-services/ourinsights/eradicating-polio-in-nigeria

Dionne, K. Y. (2012). Local demand for a global intervention: Policy priorities in the time of aids. World Development, 40, 2468-2477.

Distelhorst, G. (2015). The power of empty promises: Quasi-democratic institutions and activism in china. Comparative Political Studies, 50, 464-498.

Emergency Operation Center Nigeria. (2015). Descriptive review to document the added value of health camps in Nigeria (Tech. Rep.). Abuja, Nigeria.

Evans, P. B. (1995). Embedded autonomy: States and industrial transformation (Vol. 25). Princeton, NJ: Princeton University Press.

$\mathrm{Fu}$, D. (2016). Disguised collective action in china. Comparative Political Studies, 50, 499-527.

Gehlbach, S. (2006). A formal model of exit and voice. Rationality and Society, 18, 395-418.

Ghinai, I., Willott, C., Dadari, I., \& Larson, H. J. (2013). Listening to the rumours: What the northern Nigeria polio vaccine boycott can tell us ten years on. Global Public Health, 8, 1138-1150.

Harvard School of Public Health. (2014). Knowledge, attitudes and practices (KAPS) polls in Pakistan and Nigeria (Tech. Rep.). Harvard Opinion Research Program and UNICEF.

Hirschman, A. O. (1970). Exit, voice, and loyalty: Responses to decline in firms, organizations, and states (Vol. 25). Cambridge, MA: Harvard University Press.

Levi, M. (1989). Of rule and revenue. Berkeley: University of California Press.

Lieberman, E. (2009). The politics of demanding sacrifice: Applying insights from fiscal sociology to the study of aids policy and state capacity. In I. W. Martin, A. K. Mehrotra, \& M. Prasad (Eds.), The new fiscal sociology: Taxation in comparative and historical perspective (pp. 101-119). New York, NY: Cambridge University Press.

Lizzeri, A., \& Persico, N. (2001). The provision of public goods under alternative electoral incentives. American Economic Review, 91, 225-239.

Mcloughlin, C., \& Batley, R. (2012). The effects of sector characteristics on accountability relationships in service delivery (Overseas Development Institute Working Paper 350).

Nasir, S.-G., Aliyu, G., Ya'u, I., Gadanya, M., Mohammad, M., Zubair, M., \& El-Kamary, S. S. (2014). From intense rejection to advocacy: How Muslim 
clerics were engaged in a polio eradication initiative in northern Nigeria. PLoS Medicine, 11(8), e1001687.

National Primary Health Care Development Agency. (2013). 2014 Nigeria polio eradication emergency plan (Tech. Rep.). Retrieved from http://polioeradication. org/wp-content/uploads/2016/07/4.2_10IMB.pdf

Obadare, E. (2005). A crisis of trust: History, politics, religion and the polio controversy in northern Nigeria. Patterns of Prejudice, 39, 265-284.

O'Brien, K. J., \& Li, L. (2006). Rightful resistance in rural China. China. Cambridge, UK: Cambridge University Press.

Olson, M. (1965). Logic of collective action: Public goods and the theory of groups (Rev. ed.). Cambridge, MA: Harvard University Press.

Paler, L. (2013). Keeping the public purse: An experiment in windfalls, taxes, and the incentives to restrain government. American Political Science Review, 107, 706-725.

Prichard, W. (2015). Taxation, responsiveness and accountability in sub-saharan Africa: The dynamics of tax bargaining. Cambridge, UK: Cambridge University Press.

Renne, E. P. (2014). Parallel dilemmas: Polio transmission and political violence in northern Nigeria. Africa, 84, 466-486.

Rubinstein, A. (1982). Perfect equilibrium in a bargaining model. Econometrica: Journal of the Econometric Society, 50, 97-109.

Scott, J. C. (1985). Weapons of the weak: Everyday forms of peasant resistance. New Haven, CT: Yale University Press.

Tilly, C. (1992). Coercion, capital and European states, AD 990-1992. Oxford, UK: Blackwell.

Timmons, J. F. (2005). The fiscal contract: States, taxes, and public services. World Politics, 57, 530-567.

Tsai, L. L. (2015). Constructive noncompliance. Comparative Politics, 47, 253-279.

Yahya, M. (2007). Polio vaccines: "No thank you!" Barriers to polio eradication in northern Nigeria. African Affairs, 106, 185-204.

Zaslavsky, V., \& Brym, R. J. (1978). The functions of elections in the USSR. EuropeAsia Studies, 30, 362-371.

Zhou, X. (1993). Unorganized interests and collective action in communist china. American Sociological Review, 58, 54-73.

\section{Author Biographies}

Shelby Grossman is an assistant professor of Political Science at the University of Memphis. She is writing a book about the politics of informal trade in Nigeria.

Jonathan Phillips recently received a $\mathrm{PhD}$ from the Department of Government at Harvard University. His research focuses on the political economy of governance reform.

Leah R. Rosenzweig is a PhD candidate in the department of Political Science at the Massachusetts Institute of Technology. Her research focuses on political behavior in developing countries. 